\title{
Effects of biochar amendment on root traits and contaminant availability of maize plants in a copper and arsenic impacted soil
}

Aoife Brennan ${ }^{1 *}$, Eduardo Moreno Jiménez², Markus Puschenreiter33, José Antonio Alburquerque $^{4}$, Christine Switzer ${ }^{1}$

${ }^{1}$ Department of Civil and Environmental Engineering, University of Strathclyde, Glasgow, UK

2 Departamento de Química Agrícola, Universidad Autónoma de Madrid, 28049 Madrid, Spain

${ }^{3}$ University of Natural Resources and Life Sciences Vienna, Department of Forest and Soil Sciences, Konrad Lorenz Straße 24, A-3430 Tulln, Austria

${ }^{4}$ Área de Ecología, Departamento de Botánica, Ecología y Fisiología Vegetal, Universidad de Córdoba, 14071 Córdoba, Spain

* Corresponding author: aoife.brennan@strath.ac.uk

\begin{abstract}
Background and aims

Biochar has been proposed as a tool to enhance phytostabilisation of contaminated soils but little data are available to illustrate the direct effect on roots in contaminated soils. This work aimed to investigate specific root traits and to assess the effect of biochar amendment on contaminant availability.

Methods

Amendment with two different types of biochar, pine woodchip and olive tree pruning, was assessed in a rhizobox experiment with maize planted in a soil contaminated with significant levels of copper and arsenic.

Results
\end{abstract}


Amendment was found to significantly improve root traits compared to the control soil, particularly root mass density and root length density. Copper uptake to plants and ammonium sulphate extractable copper was significantly less in the biochar amended soils. Arsenic uptake and extractability varied with type of biochar used but was not considered to be the limiting factor affecting root and shoot development.

\section{Conclusions}

Root establishment in contaminated soils can be enhanced by biochar amendment but choice of biochar is key to maximising soil improvement and controlling contaminant availability.

Keywords: Rhizobox; phytostabilisation; biochar; contaminated soil; availability

\section{Introduction}

Restoring degraded soils using low impact, cost-effective remediation techniques has been increasingly investigated over the last few decades, given the extremely high number of contaminated sites generated in the wake of anthropogenic activities and the expense involved in remediating these sites (Onwubuya et al. 2009). Phytoremediation in the form of phytostabilisation is one low impact remediation option which aims to stabilise soil structure and reduce negative contaminant effects simultaneously (Kidd et al. 2009).

The use of degraded sites for biomass crop generation is a proposed solution for deriving commercial benefit from a phytoremediation approach (Atkinson et al. 2008). Maize (Zea mays) is one potential crop choice due to its quick growth cycle and high biomass production. It has been previously used to investigate contaminant impact on plant health and growth (Lin et al. 2008) in addition to in studies assessing its potential 
as a biomass crop grown in contaminated soil (Witters et al. 2012a; Witters et al. 2012b).

Successful phytoremediation relies on good plant development in the form of healthy root structure and high root and shoot biomass in conjunction with minimal root to shoot translocation of contaminants to minimise transfer across the food chain (Karami et al. 2011; Wenzel 2009). However, plant establishment on a contaminated site can be problematic and the use of amendments, particularly organic materials, can enhance biomass yield and improve plant health (Clemente et al. 2012). The use of biochar as an amendment for re-establishing plant growth in contaminated environments (Beesley et al. 2011; Karami et al. 2011) is one potentially cost effective approach, particularly if waste-derived biochars are used, but field derived data are scarce mainly due to concerns over increased mobility of some contaminants, particularly arsenic (Beesley et al. 2013; Beesley et al. 2010). The literature available for biochar amendment of uncontaminated/agricultural sites have highlighted the positive effects of biochar amendment on root growth (Lehmann et al. 2011; Prendergast-Miller et al. 2011; Prendergast-Miller et al. 2014) but this has not yet been fully studied in the context of contaminated soils. A wider knowledge of the effects of biochar amendment on root growth in contaminated systems is essential in addition to a better understanding of contaminant behaviour patterns before confident field scale application.

Based on the hypothesis that biochar amendment alters root growth and available contaminant pools in polluted soils, the objectives of this work were to: investigate root morphology and architecture in a contaminated soil amended with biochar using a rhizobox approach and; to assess the effect of biochar amendment on available/mobile contaminant pools in the soils and on measured plant uptake.

\section{Materials and methods}




\section{Experiment set up}

Soil was collected from the topsoil $(0-15 \mathrm{~cm})$ of the vicinity of the tailings dump of the disused copper mine El Fernandito in Garganta de los Montes (4055'3.14"N; $3^{\circ} 40^{\prime} 23.36 " \mathrm{~W}$ ), near Madrid, Spain, sieved to $2 \mathrm{~mm}$, and air dried. The soil had a sandy loam texture (54\% sand, $39 \%$ silt and $7 \%$ clay), $\mathrm{pH}$ of 6.8 , low organic matter content (1.08\%) and high total As and $\mathrm{Cu}$ concentrations (74 and $404 \mathrm{mg} \mathrm{kg}^{-1}$, respectively). The soil also contained enhanced levels of Zn and Mn (260 and $606 \mathrm{mg} \mathrm{kg}^{-1}$, respectively).

Two biochars, derived from the slow pyrolysis of pine woodchip (PB) and olive tree pruning (OB), were used to amend the contaminated soil and were lightly crushed and sieved to 0.5 to $2 \mathrm{~mm}$. Biochars were produced in a pilot plant at $450{ }^{\circ} \mathrm{C}$ with a residence time in the reactor of approximately 15 minutes. Biochar samples were produced by the University of León (Natural Resources Institute, Spain) in the framework of the project "Proyecto Biocar: Estudio del Biocarbón como Sumidero de Carbono" (IPT-4400002010-8). The biochars differed greatly in their properties as shown in Table 2.1.

Maize seeds were washed and pre-germinated before planting. They were washed by sonicating in $10 \%$ sodium hypochlorite for 30 minutes and then in deionised water for 30 minutes. They were then placed on tissue paper moistened with deionised water and several drops of calcium sulphate $(1.5 \mathrm{mM})$ and incubated at $28^{\circ} \mathrm{C}$ for 72 hours for germination.

The pre-germinated maize seeds were grown in rhizoboxes $(25 \mathrm{~cm} \times 10 \mathrm{~cm} \times 1 \mathrm{~cm})$ for 21 days in a controlled growth chamber (temperature day $25^{\circ} \mathrm{C}$ (night $20^{\circ} \mathrm{C}$ ); relative humidity day 40\% (night 60\%); hours of light day 13 hours (night 11 hours); light intensity $520 \mu \mathrm{mol} \mathrm{m}^{-2} \mathrm{~s}^{-1}$ ). $300 \mathrm{~g}$ of the contaminated mine soil was amended with $3 \%$ pine woodchip or olive tree pruning biochar (thoroughly mixed). This treatment approach is equivalent to a field application rate of approximately $50 \mathrm{t} / \mathrm{ha}$, based on an assumption of 1600-1700t soil/ha. The control treatment was not amended with char. 
All three treatment scenarios were conducted with five replicates and each replicate was planted with two seeds. A fine cloth was inserted into the bottom of the rhizobox to allow watering by capillary action, maintaining constant moisture content within the boxes. The rhizoboxes were covered with foil to exclude light and angled at $65^{\circ}$ to encourage the roots to grow on the rhizobox/soil interface (Marschner and Römheld 1983).

A column experiment set up to run in parallel to the rhizoboxes explored the differences in leaching patterns between washed and unwashed olive tree pruning biochar. Washing consisted of sonication in ethanol for two hours before rinsing three times with deionised water and air drying. $700 \mathrm{~g}$ of soil only or $700 \mathrm{~g}$ of a soil and $3 \%$ char mix was packed into Perspex columns (cylinders $40 \mathrm{~cm}$ long x $5 \mathrm{~cm}$ diameter). Each treatment was performed in duplicate columns. A peristaltic pump was set to run deionised water through the system, collecting eight fractions on an accumulated volume basis. In total, $13500 \mathrm{ml}$ of leachate was collected over 14 days and this volume simulated about 9 years of rainfall at the site from which the soil was removed.

\section{Harvesting}

After 21 days, the maize plants were harvested. Shoots were cut $1 \mathrm{~cm}$ above the soil surface, rinsed with deionised water, dried with tissue paper. Roots were sonicated twice in deionised water, rinsed and dried with tissue paper. All plant material was weighed for total fresh weight. Of the two plants per treatment replicate, one plant was used for enzymatic analyses (nitrate reductase in the shoots and acid phosphatase in the roots), and the second plant was used to determine concentrations of potentially toxic elements in the shoots after being dried at $60^{\circ} \mathrm{C}$ for 72 hours. The fresh roots of the second plant were stained with $5 \%$ Giemza Blue solution and kept at $4{ }^{\circ} \mathrm{C}$ in a ziplock bag in deionised water until root characteristics analysis was carried out using WinRhizo® software. 
Leaf area was determined by scanning (HP Photosmart C4280) and processing the images in GIMP 2 software. Root length, root surface area, diameter and diameter classes were determined by WinRhizo software following root preparation as described in the previous paragraph. Roots were scanned after being placed carefully on a transparent tray in 2-3mm of water (Himmelbauer et al. 2004).

\section{Soil and biochar analysis}

Soil particle size distribution was determined using standard method ISO 11277:2009 (ISO 2009). $\mathrm{pH}$ and electrical conductivity (EC) of the soil and biochar samples were determined in the water extract $1: 5(\mathrm{w} / \mathrm{v})$ and $1: 10(\mathrm{w} / \mathrm{v})$ respectively after stirring the mixture mechanically for 2 hours. Organic matter content (OM) was determined by loss on ignition at $550^{\circ} \mathrm{C}$ for soil and following the TMECC method for biochar (TMECC 2002).

Biochar $\mathrm{C}$ and $\mathrm{N}$ contents were determined using an elemental analyser (LECO CHN600). The water-soluble organic C (WSC), water-soluble inorganic C (WSIC) and watersoluble N (WSN) were determined using an automatic analyser for liquid samples (TOCV CSN+TNM-1 Analyser, Shimadzu). Total P, K, Ca, Mg, Fe, Mn, $\mathrm{Zn}$ and $\mathrm{Cu}$ were determined after dry ash sample digestion using method 04.12-C (TMECC 2002). Total and water soluble $(1: 10 \mathrm{w} / \mathrm{v})$ components were analysed as follows: $\mathrm{P}$ was determined colorimetrically (Murphy and Riley 1962); K by atomic emission spectroscopy; Ca, Mg, $\mathrm{Fe}, \mathrm{Mn}, \mathrm{Zn}$ and $\mathrm{Cu}$ by atomic absorption spectrophotometry and; As by atomic fluorescence spectroscopy (Millennium Excalibur, PS Analytical).

The liming value of biochar was measured as calcium carbonate equivalency according to the 04.08-A method (TMECC 2002). The biochar bulk density was estimated by weighing $10 \mathrm{~mL}$ of milled sample. The $\mathrm{CO}_{2}$ adsorption method $(273 \mathrm{~K})$ using a Micromeritics ASAP 2020 instrument was performed to determine the surface area of the biochar samples. All biochar samples were degassed under vacuum at $200^{\circ} \mathrm{C}$ for 8 
hours prior to analysis. Cation exchange capacity (CEC) was measured by a modified ammonium-acetate compulsory displacement method (Gaskin et al. 2008). The germination index (GI) was determined using cress (Lepidium sativum L.) and lettuce (Lactuca sativa L.) (Zucconi et al. 1981).

Plant enzyme analysis and soil and plant tissue analysis of potentially toxic elements (PTEs)

Samples of $0.25 \mathrm{~g}$ fresh shoot material and $0.25 \mathrm{~g}$ fresh root material were extracted for nitrate reductase activity (Ruiz et al. 1999) and acid phosphatase activity respectively (Barrett-Lennard and Greenway 1982).

Total and extractable As concentrations in the treatments were determined by atomic fluorescence spectroscopy (Millennium Excalibur, PS Analytical) and $\mathrm{Cu}, \mathrm{Zn}$ and $\mathrm{Mn}$ was determined by atomic absorption spectroscopy (AA800, Perkin Elmer) following autoclaving (Lozano-Rodriguez et al. 1995) and ammonium sulphate extraction (Vázquez et al. 2008) respectively. For total soil concentrations, $0.5 \mathrm{~g}$ of soil was transferred into $50 \mathrm{ml}$ autoclave bottles to which $6 \mathrm{ml}$ of MilliQ water, $6 \mathrm{ml}$ of $65 \% \mathrm{HNO}_{3}$ and $4 \mathrm{ml}$ of $33 \% \mathrm{H}_{2} \mathrm{O}_{2}$ were added. The autoclave was set at a pressure of $1.5 \mathrm{~kg} \mathrm{~cm}^{-2}$ $\left(125^{\circ} \mathrm{C}\right)$ for 30 minutes, samples were left to cool, then filtered and made up to $50 \mathrm{ml}$. Total plant concentrations (shoot tissue) were determined by weighing $0.1 \mathrm{~g}$ dried shoot tissue into $20 \mathrm{ml}$ autoclave bottles to which $2 \mathrm{ml}$ of MilliQ water, $1.5 \mathrm{ml}$ of $65 \%$ $\mathrm{HNO}_{3}$ and $1 \mathrm{ml}$ of $33 \% \mathrm{H}_{2} \mathrm{O}_{2}$ were added and made up to $5 \mathrm{ml}$ once autoclaved, cooled and filtered. Extractable PTEs in the soils were determined by extracting $1.5 \mathrm{~g}$ of soil with $15 \mathrm{ml}$ of $\left(\mathrm{NH}_{4}\right)_{2} \mathrm{SO}_{4} 0.1 \mathrm{M}$ in $50 \mathrm{ml}$ tubes and shaking for four hours at $180 \mathrm{rpm}$. The samples were then filtered and $0.1 \mathrm{ml}$ of $\mathrm{HNO}_{3}$ was added. 


\section{Column leachate analysis}

Column leachate fractions were analysed for $\mathrm{pH}$, EC and DOC. Nitrate, chloride, phosphate and sulphate were analysed by ion chromatography (Dionex). As and $\mathrm{Cu}$ in the leachate were determined as described in the previous section.

\section{Data analysis}

Statistical analyses were carried out on SPSS. Data were checked to fit the hypothesis of normality and homoscedasticity. All data were normally distributed and were tested with a one-way ANOVA. Tukey's test was used as post-hoc for mean comparisons of the homoscedastic data. Games-Howell's test was used for the comparisons of nonhomoscedastic data.

\section{Results}

\section{Effect of biochar on shoot and root traits}

Biochar amendment had a positive effect on most of the measured plant characteristics (Figs. 2.1-2.3). Biochar amendment significantly affected fresh shoot/root ratio (Fig. 2.1), which for both pine woodchip (PB) and olive tree pruning biochar (OB) amendments was greater than the control. In the PB treatment, the higher shoot/root ratio was due to an increase in shoot biomass while root biomass did not significantly differ compared to the control.. When amended with OB, both root and shoot biomass increased significantly compared to the control, in addition to the increase in the observed shoot/root ratio.

Leaf surface area significantly increased $(\mathrm{p}<0.05)$ in both biochar amended soils compared to the control. The same pattern was observed for root length and root surface area (both at $\mathrm{p}<0.01$ ) (Fig. 2.2). By classifying the different root diameters into percentage composition (Fig. 2.3), root diameters $<0.4 \mathrm{~mm}$ seem predominant in the 
biochar amended soils $(>50 \%)$ compared to less than $30 \%$ in the control while root diameters of $>1 \mathrm{~mm}$ represent less than $5 \%$ in the char amended soils compared to more than $25 \%$ in the control. These results suggest that both PB and OB promoted root growth and production of fine roots. Likewise, both $\mathrm{OB}$ and $\mathrm{PB}$ amendment led to significantly higher root length density $(\mathrm{p}<0.01)$ compared to the control. Specific root length was significantly higher in the PB amended soil compared to the control $(\mathrm{p}<0.05)$, but this was not the case in the $\mathrm{OB}$ amended soil. In terms of root morphology, root length: root volume ratios were similar across treatments, while root tissue density was significantly lower in the PB treatment compared to the control at $0.1 \%$ versus $0.5 \%$ $(\mathrm{p}<0.05)$. Biochar amendment had a generally beneficial effect on plant resource allocation below ground, but this was not the case for all parameters. OB amended soils had a significantly higher root mass density than both PB amended soils and the control soils $(\mathrm{p}<0.01)$. Root length ratio was significantly greater in the PB treatment than both the control and the $\mathrm{OB}$ treatment $(\mathrm{p}<0.05)$. Root weight ratio was significantly lower in the PB amended soils compared to the control $(\mathrm{p}<0.05)$, suggesting PB amendment enabled the plant to allocate more resources to above ground (Table 2.2).

\section{Effect of biochar on PTE extractability and plant uptake}

The different biochars behaved very differently with regards to PTE extractability in the soils (Fig. 2.4). There was no significant difference in arsenic extractability between the control and PB amended soil, while $\mathrm{OB}$ amended soils had significantly higher extractable arsenic (at $\mathrm{p}<0.05)$. In contrast, both biochar amendments significantly decreased copper extractability compared to the control $(\mathrm{p}<0.01)$. Zinc extractability significantly decreased across treatments, in the order Control $>\mathrm{PB}>\mathrm{OB}(\mathrm{p}<0.05)$ while no significant differences were observed for Mn extractability (Fig. 2.5).

The patterns observed in PTE shoot uptake were slightly different (Fig. 2.6-2.7). Arsenic uptake in the shoots differed significantly between the two biochar treatments, with PB 
treatments had significantly less shoot arsenic than OB treatments $(\mathrm{p}<0.05)$, although neither amendment differed significantly to the control. On the other hand, there was significantly less copper in the plant shoots from both the biochar treatments compared to the control $(\mathrm{p}<0.01)$. Shoot $\mathrm{Zn}$ and $\mathrm{Mn}$ concentrations were significantly reduced in the OB treatment compared to the control $(\mathrm{p}<0.05)$, but not in the PB treatment compared to the control.

Plant enzymatic activities as affected by biochar application

A significant downward trend was observed for nitrate reductase activity in plant shoots for $\mathrm{OB}$ amended soils compared to the control, while no differences were observed between the control and PB amendment. No significant differences were observed in acid phosphatase activity in the roots across treatments (Fig. 2.8).

\section{Arsenic, copper and anion leaching after biochar application}

Whereas As leaching rates were constant in the control soils, the olive tree pruning biochar significantly increased arsenic concentrations in the percolate water (Fig. 2.9). Although the washed biochar (WBC) reduced arsenic leaching from the column compared to the unwashed biochar (BC), the leachable portion of arsenic is very similar between the washed and unwashed chars (Table 2.3).

Dissolved organic carbon increased across treatments as highlighted by the cumulative totals: $1.5 \mathrm{mg} \mathrm{kg}^{-1}(+/-0.02 \mathrm{SE})$ in the soil columns, $220.6 \mathrm{mg} \mathrm{kg}^{-1}$ in the unwashed biochar columns and $95.7 \mathrm{mg} \mathrm{kg}^{-1}(+/-15.9 \mathrm{SE})$ in the washed biochar columns. Chloride leaching decreased with $\mathrm{OB}$ amendment while nitrate leaching significantly increased. Most phosphate fractions were below detection limits while there was no observed effect on sulphate concentrations (Table 2.4).

\section{Discussion}




\section{Effect of biochar amendment on contaminant mobility}

Results from the current study suggest that biochar amendment promotes root growth, increases available pools of arsenic for plant uptake while decreasing those of copper and zinc. The variable effect on arsenic availability in the soil according to char type (As in $\mathrm{OB}>\mathrm{As}$ in $\mathrm{PB}$ ) may be explained by the $\mathrm{OB}$ having a more available arsenic content as a result of its more alkaline $\mathrm{pH}$ and relatively high carbonate and soluble $\mathrm{P}$ contents compared to PB (Table 2.1). Additional soil and plant interactions over the course of the experiment may also have contributed to the observed data. As others have also suggested, char type needs to be chosen on a site specific basis (Beesley et al. 2011). Increased arsenic availability has also been observed in other studies in soil only and soil and plant systems (Beesley et al. 2010; Karami et al. 2011). The arsenic content in the olive tree pruning biochar itself and the increased $\mathrm{pH}$ caused by $\mathrm{OB}$ amendment (Table 2.1) may also be contributing to the increased arsenic release observed in the columns (Fig. 2.9). The leachable pool of copper observed in the unamended soil columns was doubled in the washed biochar and soil columns and tripled in the unwashed biochar and soil columns (Table 2.3). This is likely related to the enhanced concentrations of dissolved organic carbon (DOC) with biochar addition. Comparing the patterns observed for arsenic and copper in the soil control column, $\mathrm{Cu}$ is more easily leachable while arsenic appears to be poorly mobile. The data from the biochar amended columns illustrate that $\mathrm{OB}$ mobilises $\mathrm{As}$ to a greater extent than $\mathrm{Cu}$. One previous study suggested that biochar amendment triggered a higher leaching capacity for As but not for $\mathrm{Cu}$ (Beesley and Marmiroli 2011). There are several possible explanations for this, the most likely being due to differences in biochar feedstock properties although differences in experimental design between the present study and the cited study may also be a contributing factor in the patterns observed. Nonetheless, although column studies are useful to get an idea of contaminant leaching capacity, they 
do not fully represent a field scenario where plant interactions also have an effect on contaminant leaching.

\section{Effect of biochar amendment on nutrient availability}

Nitrate reductase is the enzyme responsible for reducing nitrate to nitrite. Lower activity here indicates less availability of nitrate to the plant shoots for conversion, which may have been caused by sorption of nitrate to the biochar particles (Jones et al. 2012). Biochar localises nitrate in the rhizosphere of biochar amended soils, resulting in less nitrate uptake by plants (Prendergast-Miller et al. 2011). Nonetheless, N dynamics are highly complex and a number of factors may be at play for the results presented (Clough et al. 2013).

In the case of the phosphatase enzyme, the reduced activity may be due to the increased uptake of arsenic observed in the plants and therefore reduced phosphate uptake, considering As is a well reported P analogue (Meharg and MacNair 1992; Moreno Jimenez et al 2008). Overall, the reduced enzymatic activity may be due to nutrient, enzyme or substrate sorption to the biochar (Lehmann et al. 2011). Variability in soil enzyme activity in the presence of char has been reported elsewhere (Bailey et al. 2011; Jones et al. 2012; Lehmann et al. 2011) although no specific data are available for plant enzymes in biochar amended soils.

The availability of other nutrients (e.g. $\mathrm{K}, \mathrm{Mg}$, Ca) in each treatment was not determined, thus the possibility that the addition of $\mathrm{K}$ or other nutrients due to biochar amendment (see biochar properties in Table 2.1) may have contributed to the improved plant growth cannot be ruled out. Although this aspect may be a potentially confounding factor in the results presented, this potential nutrient addition from biochar amendment would play a more significant role in agricultural soils or in a longer term experiment. Further studies elucidating interactions between nutrients and contaminants in 
contaminated soils with respect to plant growth are required before making any conclusions on this matter.

Root response to biochar amendment in contaminated systems

Contaminant availability tends to be the principal limiting factor affecting plant growth in contaminated soils. The nutrient limitation commonly found in mine soils is another important factor. However, given the significant reductions in copper availability with biochar amendment (both in terms of extractability and actual uptake) and the corresponding improvements in root development with biochar amendment, our results suggest that excess copper was limiting plant establishment and survival in the presented study. The less consistent behaviour of the other contaminants compared to copper lend credence to this theory.

This study suggests that biochar has no clear detrimental effect on root establishment and, by reducing copper availability significantly in both char treatments, a net positive effect was observed, particularly with regards to root mass density and root length density. Another study found that biochar effects on root traits in agricultural soils were not as indicative of root behaviour as quantifying rhizosheath development and biochar particles in the rhizosphere (Prendergast-Miller et al. 2013). However, in contaminated soils, root traits appear to be useful indicators of root responses to biochar amendment compared to unamended contaminated controls, with significant differences observed across the majority of indicators. There is a scarcity of data investigating specific root responses to biochar amendment in contaminated systems, apart from some qualitative assessment (Beesley et al. 2013) and further studies are needed in order to fully evaluate the effects on a range of plants and in a range of contaminated soils.

Implications for phytomanagement of mine soils 
These results suggest that biochar addition to contaminated mine soils may enhance plant cover by improving root development and promoting higher biomass both above and below ground. Not only are these soils affected by contamination, they tend to have poor physical properties and low nutrient and carbon statuses which can make plant establishment difficult. It appears that biochar amendment reduces soil toxicity to plants growing under these difficult conditions, at least in early stages of plant establishment, and may play a role in limiting contaminant dispersion. In terms of improving soil health, other studies have highlighted the beneficial effects of biochar addition to poor soils, for example, improved water holding capacity and cation exchange capacity (Busscher et al. 2010; Carter et al. 2013; Revell et al. 2012; Sukartono et al. 2011). If the trends observed in this study can be further demonstrated under field conditions, biochar will become a valuable yet affordable tool in the phytomanagement of degraded soils.

\section{Conclusions}

Root establishment in contaminated soils can be enhanced by biochar amendment but choice of biochar is key to maximising soil improvement, controlling contaminant availability to plants and controlling contaminant mobility overall.

\section{Acknowledgments}

This work was carried out as part of a STSM awarded to the lead author by EU COST Action TD1107 Biochar as an option for sustainable resource management. We thank Dr Peter Anderson at SETN (Scottish Environmental Technology Network) for the IC analysis. We thank Dr Saran Sohi of the UKBRC, Edinburgh, for checking the manuscript before submission. We also thank the two anonymous reviewers for improving the manuscript with their comments.

\section{References}


Atkinson J, Lane A, Lord R, Street G, Scurlock J (2008) Biomass, Remediation, ReGeneration (BioReGen Life Project): Reusing Brownfield Sites for Renewable Energy Crops. GeoCongress 2008.

Bailey VL, Fansler SJ, Smith JL, Bolton Jr H (2011) Reconciling apparent variability in effects of biochar amendment on soil enzyme activities by assay optimization. Soil Biology and $\quad$ Biochemistry 296-301. doi: http://dx.doi.org/10.1016/j.soilbio.2010.10.014.

Barrett-Lennard EG, Greenway H (1982) Partial Separation and Characterization of Soluble Phosphatases from Leaves of Wheat Grown Under Phosphorus Deficiency and Water Deficit. Journal of Experimental Botany 33: 694-704. doi: 10.1093/jxb/33.4.694. Beesley L, Marmiroli M (2011) The immobilisation and retention of soluble arsenic, cadmium and zinc by biochar. Environmental Pollution 159: 474-480. doi: 10.1016/j.envpol.2010.10.016.

Beesley L, Marmiroli M, Pagano L, Pigoni V, Fellet G, Fresno T, Vamerali T, Bandiera M, Marmiroli N (2013) Biochar addition to an arsenic contaminated soil increases arsenic concentrations in the pore water but reduces uptake to tomato plants (Solanum lycopersicum L.). Science of The Total Environment 454-455: 598-603. doi: http://dx.doi.org/10.1016/j.scitotenv.2013.02.047.

Beesley L, Moreno-Jiménez E, Gomez-Eyles JL (2010) Effects of biochar and greenwaste compost amendments on mobility, bioavailability and toxicity of inorganic and organic contaminants in a multi-element polluted soil. Environmental Pollution 158: 2282-2287. doi: 10.1016/j.envpol.2010.02.003.

Beesley L, Moreno-Jiménez E, Gomez-Eyles JL, Harris E, Robinson B, Sizmur T (2011) A review of biochars' potential role in the remediation, revegetation and restoration of contaminated soils. Environmental Pollution 159: 3269-3282. doi: 10.1016/j.envpol.2011.07.023. 
Busscher WJ, Novak JM, Evans DE, Watts DW, Niandou MAS, Ahmedna M (2010) Influence of Pecan Biochar on Physical Properties of a Norfolk Loamy Sand. Soil Science 175: 10-14.

Carter S, Shackley S, Sohi S, Suy TB, Haefele S (2013) The Impact of Biochar Application on Soil Properties and Plant Growth of Pot Grown Lettuce (Lactuca sativa) and Cabbage (Brassica chinensis). Agronomy 3: 404-418. doi: doi:10.3390/agronomy3020404.

Clemente R, Walker DJ, Pardo T, Martínez-Fernández D, Bernal MP (2012) The use of a halophytic plant species and organic amendments for the remediation of a trace elements-contaminated soil under semi-arid conditions. Journal of Hazardous Materials 223-224: 63-71. doi: http://dx.doi.org/10.1016/j.jhazmat.2012.04.048.

Clough T, Condron L, Kammann C, Müller C (2013) A Review of Biochar and Soil Nitrogen Dynamics. Agronomy 3: 275-293.

Gaskin JW, Steiner C, Harris K, Das KC, Bibens B (2008) Effect of Low-Temperature Pyrolysis Conditions on Biochar for Agricultural Use. 51.

Himmelbauer ML, Loiskandl AW, Kastanek AF (2004) Estimating length, average diameter and surface area of roots using two different Image analyses systems. Plant and Soil 260: 111-120. doi: 10.1023/b:plso.0000030171.28821.55.

ISO (2009) Soil quality Determination of particle size distribution in mineral soil material Method by sieving and sedimentation.

Jones DL, Rousk J, Edwards-Jones G, DeLuca TH, Murphy DV (2012) Biochar-mediated changes in soil quality and plant growth in a three year field trial. Soil Biology and Biochemistry 45: 113-124. doi: 10.1016/j.soilbio.2011.10.012.

Karami N, Clemente R, Moreno-Jiménez E, Lepp NW, Beesley L (2011) Efficiency of green waste compost and biochar soil amendments for reducing lead and copper mobility and uptake to ryegrass. Journal of Hazardous Materials 191: 41-48. doi: 10.1016/j.jhazmat.2011.04.025. 
Kidd P, Barceló J, Bernal MP, Navari-Izzo F, Poschenrieder C, Shilev S, Clemente R, Monterroso C (2009) Trace element behaviour at the root-soil interface: Implications in phytoremediation. Environmental and Experimental Botany 67: 243-259. doi: http://dx.doi.org/10.1016/j.envexpbot.2009.06.013.

Lehmann J, Rillig MC, Thies J, Masiello CA, Hockaday WC, Crowley D (2011) Biochar effects on soil biota - A review. Soil Biology and Biochemistry 43: 1812-1836. doi: 10.1016/j.soilbio.2011.04.022.

Lin Q, Shen K-L, Zhao H-M, Li W-H (2008) Growth response of Zea mays L. in pyrenecopper co-contaminated soil and the fate of pollutants. Journal of Hazardous Materials 150: 515-521. doi: http://dx.doi.org/10.1016/j.jhazmat.2007.04.132.

Lozano-Rodriguez E, Luguera M, Lucena JJ, Carpena-Ruiz R (1995) Evaluation of two different acid digestion methods in closed systems for trace element determinations in plants. Quimica Analitica 14: 27-30.

Marschner H, Römheld V (1983) In vivo Measurement of Root-induced pH Changes at the Soil-Root Interface: Effect of Plant Species and Nitrogen Source. Zeitschrift für Pflanzenphysiologie 111: 241-251. doi: http://dx.doi.org/10.1016/S0044$\underline{328 X(83) 80083-X}$.

Murphy J, Riley JP (1962) A modified single solution method for the determination of phosphate in natural waters. Analytica Chimica Acta 27: 31-36. doi: http://dx.doi.org/10.1016/S0003-2670(00)88444-5.

Onwubuya K, Cundy A, Puschenreiter M, Kumpiene J, Bone B, Greaves J, Teasdale P, Mench M, Tlustos P, Mikhalovsky S, Waite S, Friesl-Hanl W, Marschner B, Müller I (2009) Developing decision support tools for the selection of "gentle" remediation approaches. Science of The Total Environment 407: 6132-6142. doi: http://dx.doi.org/10.1016/j.scitotenv.2009.08.017. 
Prendergast-Miller MT, Duvall M, Sohi SP (2011) Localisation of nitrate in the rhizosphere of biochar-amended soils. Soil Biology and Biochemistry 43: 2243-2246. doi: 10.1016/j.soilbio.2011.07.019.

Prendergast-Miller MT, Duvall M, Sohi SP (2014) Biochar-root interactions are mediated by biochar nutrient content and impacts on soil nutrient availability. European Journal of Soil Science: 65: 173-185. doi: 10.1111/ejss.12079.

Revell KT, Maguire RO, Agblevor FA (2012) Influence of Poultry Litter Biochar on Soil Properties and Plant Growth. Soil Science. doi: 10.1097/SS.0b013e3182564202.

Ruiz JM, Rivero RM, Garcia PC, Baghour M, Romero L (1999) Role of CaCl2 in nitrate assimilation in leaves and roots of tobacco plants (Nicotiana tabacum L.). Plant Science 141: 107-115. doi: http://dx.doi.org/10.1016/S0168-9452(98)00230-1.

Sukartono, Utomo WH, Kusuma Z, Nugroho WH (2011) Soil fertility status, nutrient uptake, and maize (Zea mays L.) yield following biochar and cattle manure application on sandy soils of Lombok, Indonesia. Journal of Tropical Agriculture 49: 47-52.

TMECC (2002) Test Methods for the Examination of Composting and Compost. US Composting Council, Bethesda, MD.

Vázquez S, Moreno E, Carpena R (2008) Bioavailability of metals and As from acidified multicontaminated soils: Use of white lupin to validate several extraction methods. Environmental Geochemistry and Health 30: 193-198. doi: 10.1007/s10653-008-91433.

Wenzel W (2009) Rhizosphere processes and management in plant-assisted bioremediation (phytoremediation) of soils. Plant and Soil 321: 385-408. doi: 10.1007/s11104-008-9686-1.

Witters N, Mendelsohn R, Van Passel S, Van Slycken S, Weyens N, Schreurs E, Meers E, Tack F, Vanheusden B, Vangronsveld J (2012a) Phytoremediation, a sustainable remediation technology? II: Economic assessment of $\mathrm{CO} 2$ abatement through the use of 
phytoremediation crops for renewable energy production. Biomass and Bioenergy 39: 470-477. doi: http://dx.doi.org/10.1016/j.biombioe.2011.11.017.

Witters N, Mendelsohn RO, Van Slycken S, Weyens N, Schreurs E, Meers E, Tack F, Carleer R, Vangronsveld J (2012b) Phytoremediation, a sustainable remediation technology? Conclusions from a case study. I: Energy production and carbon dioxide

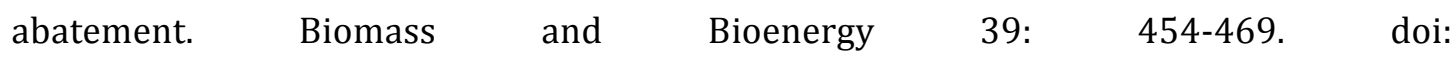
http://dx.doi.org/10.1016/j.biombioe.2011.08.016.

Zucconi F, Pera A, Forte M, de Bertoldi M (1981) Evaluating toxicity of immature compost. Biocycle 22: 54-57. 
Table 1 Main characteristics (on a dry weight basis) of the two biochars (PB: pine woodchip biochar and OB: olive tree pruning biochar). * Data provided by J.A.

Albuquerque.

\begin{tabular}{|c|c|c|}
\hline Parameters & PB & OB \\
\hline Bulk density $\left(\mathrm{g} \mathrm{cm}^{-3}\right)$ & 0.63 & 0.36 \\
\hline Liming equivalence $\left(\mathrm{g} \mathrm{CaCO}_{3} \mathrm{~kg}^{-1}\right)$ & 7.4 & 80.1 \\
\hline $\mathrm{pH}^{\mathrm{a}}$ & 7.52 & 9.34 \\
\hline Electrical conductivitya $\left(\mu \mathrm{S} \mathrm{cm}^{-1}\right)$ & 256 & 2430 \\
\hline Organic matter ( $\left.\mathrm{g} \mathrm{kg}^{-1}\right)$ & 981.9 & 900.3 \\
\hline$C\left(g_{k g}^{-1}\right)$ & 837.1 & 755.2 \\
\hline$N\left(g_{k g}^{-1}\right)$ & 3.6 & 11.0 \\
\hline$P\left(\mathrm{mg} \mathrm{kg}^{-1}\right)$ & 148 & 1464 \\
\hline $\mathrm{K}\left(\mathrm{mg} \mathrm{kg}^{-1}\right)$ & 1708 & 9159 \\
\hline $\mathrm{Ca}\left(\mathrm{mg} \mathrm{kg}^{-1}\right)$ & 3316 & 28524 \\
\hline $\operatorname{Mg}\left(\mathrm{mg} \mathrm{kg}^{-1}\right)$ & 574 & 2088 \\
\hline $\mathrm{Fe}\left(\mathrm{mg} \mathrm{kg}^{-1}\right)$ & 200 & 496 \\
\hline $\mathrm{Mn}\left(\mathrm{mg} \mathrm{kg}{ }^{-1}\right)$ & 153 & 50 \\
\hline $\mathrm{Zn}\left(\mathrm{mg} \mathrm{kg}^{-1}\right)$ & 42 & 24 \\
\hline $\mathrm{Cu}\left(\mathrm{mg} \mathrm{kg}{ }^{-1}\right)$ & 134 & 114 \\
\hline As (mg kg-1) & 1.7 & 6.1 \\
\hline Specific surface area $\left(\mathrm{m}^{2} \mathrm{~g}^{-1}\right)$ & 288 & 265 \\
\hline Germination index (lettuce, \%) & 92 & 100 \\
\hline Germination index (cress, \%) & 117 & 84 \\
\hline Cation exchange capacity ( $\left.\mathrm{cmol} \mathrm{kg}^{-1}\right)$ & 12.6 & 36.6 \\
\hline \multicolumn{3}{|l|}{ Water-soluble fractions } \\
\hline Water-soluble organic C (WSC, $\mathrm{mg} \mathrm{kg}^{-1}$ ) & 920 & 1527 \\
\hline Water-soluble inorganic $\mathrm{C}\left(\mathrm{mg} \mathrm{kg}^{-1}\right)$ & 122 & 1020 \\
\hline Water-soluble N (WSN, mg kg-1) & 10 & 19 \\
\hline WSC/WSN & 90 & 82 \\
\hline Water-soluble P (mg kg-1) & 6 & 17 \\
\hline Water-soluble $\mathrm{K}\left(\mathrm{mg} \mathrm{kg}^{-1}\right)$ & 256 & 2546 \\
\hline
\end{tabular}

awater extract $1: 10(\mathrm{w} / \mathrm{v})$. 
Table 2 Root architecture (1); root morphology (2); plant resource allocation below ground (3). Letters denote statistical significance, $p<0.05^{*},<0.01^{* *},<0.001^{* * *}$, n.s. not significant. PB: pine woodchip biochar and OB: olive tree pruning biochar.

\begin{tabular}{|c|c|c|c|c|c|c|}
\hline & & & Control & PB & OB & Sig \\
\hline \multirow[t]{2}{*}{1} & root length density & root length/ soil volume $\mathrm{mg} \mathrm{cm}^{-3}$ & $0.447(0.036) \mathrm{a}$ & $1.36(0.162) \mathrm{b}$ & $1.289(0.233) b$ & $* *$ \\
\hline & specific root length & root length/root biomass $\mathrm{cm}$ mg - & $0.106(0.015) \mathrm{a}$ & $0.313(0.08) \mathrm{b}$ & $0.141(0.025) \mathrm{a}$ & $* *$ \\
\hline \multirow[t]{2}{*}{2} & $\begin{array}{l}\text { root length: root } \\
\text { volume ratio }\end{array}$ & root length/root volume $\mathrm{cm} \mathrm{cm}^{-3}$ & $453.3(35.9)$ & $475.3(72.2)$ & $510.0(38.9)$ & n.s. \\
\hline & root tissue density & root biomass/root volume $\mathrm{mg} \mathrm{cm}_{3}^{-}$ & $\begin{array}{c}4523.0(521.2) \\
b\end{array}$ & $1682.9(257.1) \mathrm{a}$ & $\begin{array}{c}4412.1(1217.7) \\
b\end{array}$ & $*$ \\
\hline \multirow[t]{3}{*}{3} & root mass density & root biomass/ soil volume $\mathrm{mg} \mathrm{cm}_{3}^{-}$ & $4.424(0.431)$ a & $5.106(1.294) \mathrm{a}$ & 9.173 (0.499) b & $* *$ \\
\hline & root weight ratio & $\begin{array}{c}\text { root biomass/plant biomass mg } \\
\mathrm{mg}^{-1}\end{array}$ & $0.619(0.028) b$ & $0.484(0.055) \mathrm{a}$ & $\begin{array}{c}0.526(0.018) \\
\mathrm{ab}\end{array}$ & $* *$ \\
\hline & root length ratio & root length/plant biomass $\mathrm{cm}$ mg & $0.065(0.009)$ a & $0.143(0.029) \mathrm{b}$ & $0.074(0.013) \mathrm{a}$ & $* *$ \\
\hline
\end{tabular}

Table 3 Curve parameters after fitting As and $\mathrm{Cu}$ leaching data to volume of leachate (after Fig. 7). In the hyperbolic curve, the term $a$ is associated to the maximum cumulative leaching of $\mathrm{As} / \mathrm{Cu}$ (in $\mathrm{mg} \mathrm{kg}^{-1}$ ) and $b$ is associated to the volume (in L) needed to leach half of the maximum leaching. Statistical significance is indicated by ${ }^{* * *} \mathrm{p}<0.001$. WBC: washed olive tree pruning biochar and $\mathrm{BC}$ : unwashed olive tree pruning biochar.

\begin{tabular}{|c|c|c|c|c|}
\hline \multicolumn{4}{|l|}{ As } & \\
\hline \multirow{4}{*}{ Soil } & $\mathrm{a}$ & $\mathrm{y}_{0}$ & Adj. $R^{2}$ & Sig. \\
\hline & $4.1 \cdot 10^{-6}$ & 0.0086 & 0.66 & $* * *$ \\
\hline & \multicolumn{4}{|c|}{ Hyperbola: $y=a x /(b+x)$} \\
\hline & $\mathrm{a}$ & $\mathrm{b}$ & Adj. $R^{2}$ & Sig. \\
\hline Soil+WBC & 4.7 & 12.8 & 0.99 & $* * *$ \\
\hline Soil+BC & 4.5 & 7.5 & 0.99 & $* * *$ \\
\hline \multicolumn{5}{|l|}{$\mathrm{Cu}$} \\
\hline & \multicolumn{4}{|c|}{ Hyperbola: $y=a x /(b+x)$} \\
\hline & $\mathrm{a}$ & B & Adj. $R^{2}$ & Sig. \\
\hline Soil & 0.29 & 2.0 & 0.96 & $* * *$ \\
\hline Soil+WBC & 0.48 & 1.8 & 0.98 & $* * *$ \\
\hline Soil+BC & 0.91 & 1.5 & 0.97 & $* * *$ \\
\hline
\end{tabular}

Table 4 Cumulative total of 8 column leachate fractions (SE $\mathrm{n}=2$ ) expressed as mg kg-1 dry weight soil

\begin{tabular}{lccc}
\hline & $\begin{array}{l}\text { Control (soil } \\
\text { only) }\end{array}$ & $\begin{array}{l}\text { 3\% washed } \\
\text { OB }\end{array}$ & 3\% unwashed OB \\
\hline N03 & $113(70)$ & $386(115)$ & $1189(59.6)$ \\
P04 & $2.73(2.27)$ & $2.98(1)$ & $1.5(0.71)$ \\
S04 & $31(6)$ & $20.2(5.08)$ & $32.32(4.12)$ \\
Cl & $532(347)$ & $74.5(5.3)$ & $61.4(12.1)$ \\
\hline
\end{tabular}




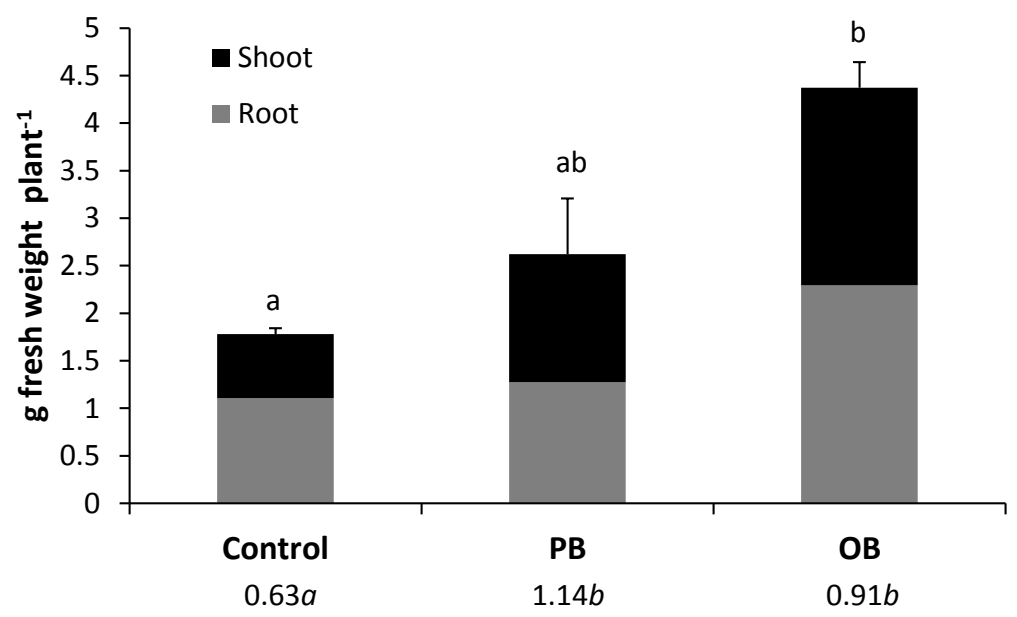

Fig. 1 Plant biomass (g of fresh weight per maize plant) in the mine soil with different biochars (PB: pine woodchip biochar and OB: olive tree pruning biochar). Mean $\pm \mathrm{SE}$ $(n=4-5)$. The shoot: root ratio was calculated and shown on the bottom of the $x$ axis. Different letters indicate statistical differences between groups at $\mathrm{p}<0.05$.
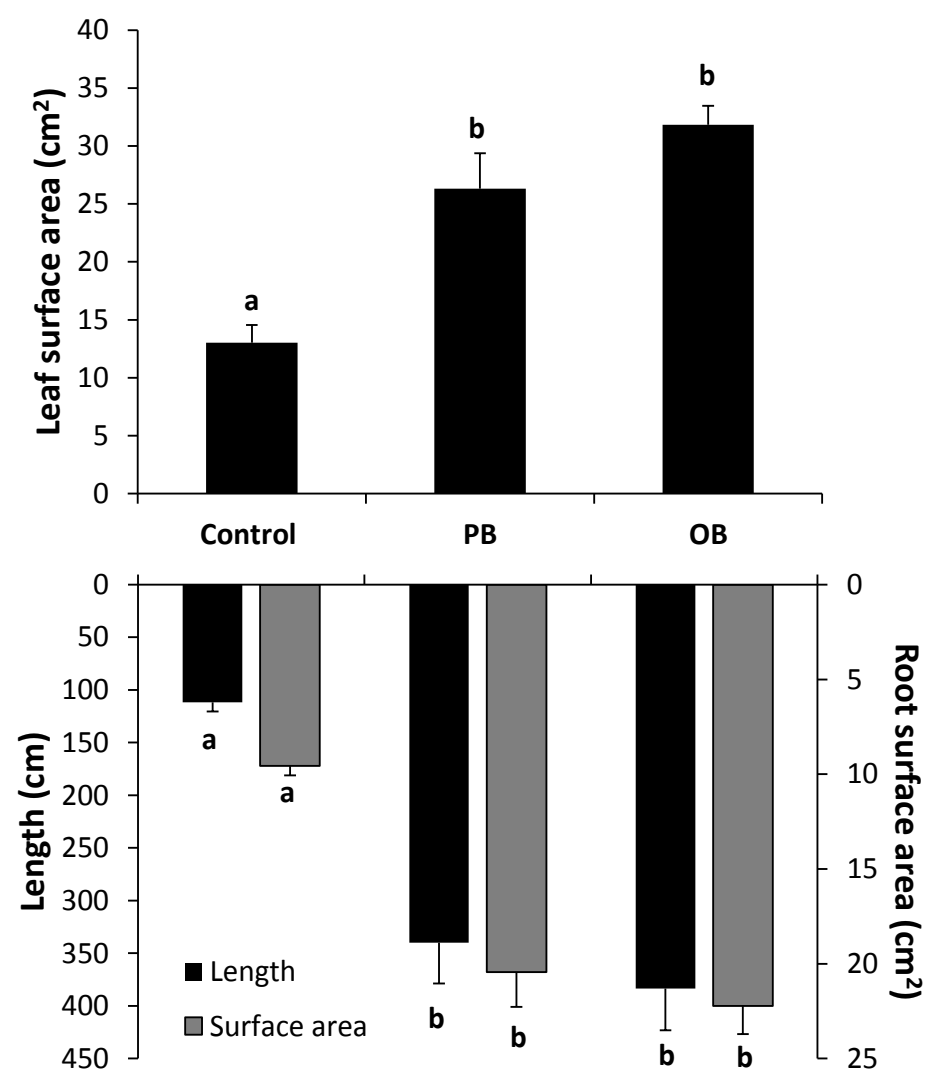

Fig. 2 Plant morphology as affected by biochar application to a mine soil: leaf surface area (top) and root length and root surface area (bottom). Mean \pm SE $(n=4-5)$. Different letters mean statistical differences between groups at $p<0.05$. PB: pine woodchip biochar and OB: olive tree pruning biochar. 


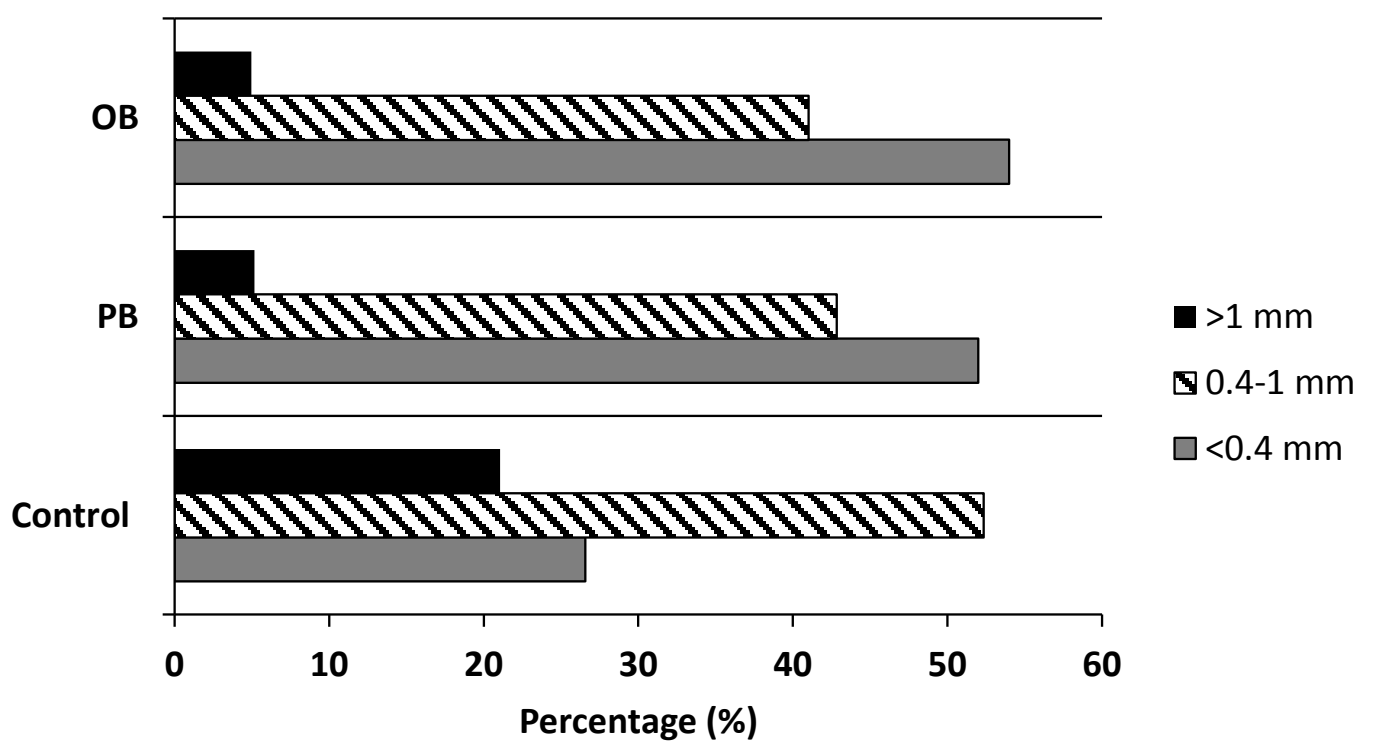

Fig. 3 Root diameter classes as affected by biochar application to a mine soil. Mean \pm SE $(n=4-5)$, where absent, error bars fall within symbols. PB: pine woodchip biochar and OB: olive tree pruning biochar.
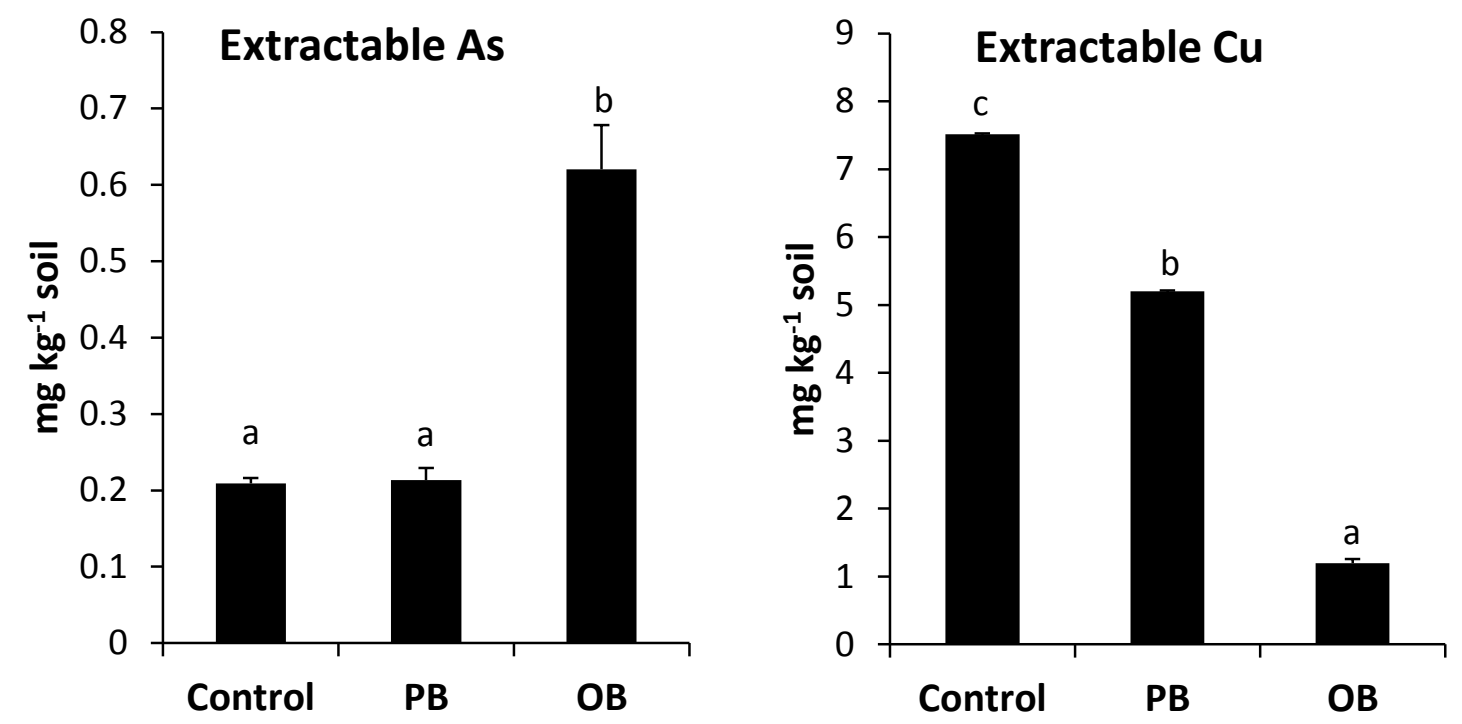

Fig. 4 Ammonium sulphate-extractable $\mathrm{As}$ and $\mathrm{Cu}$ in a mine soil with different biochar treatment (PB: pine woodchip biochar and OB: olive tree pruning biochar). Mean \pm SE $(n=5)$. Different letters signify statistical differences between treatments at $\mathrm{p}<0.05$. 

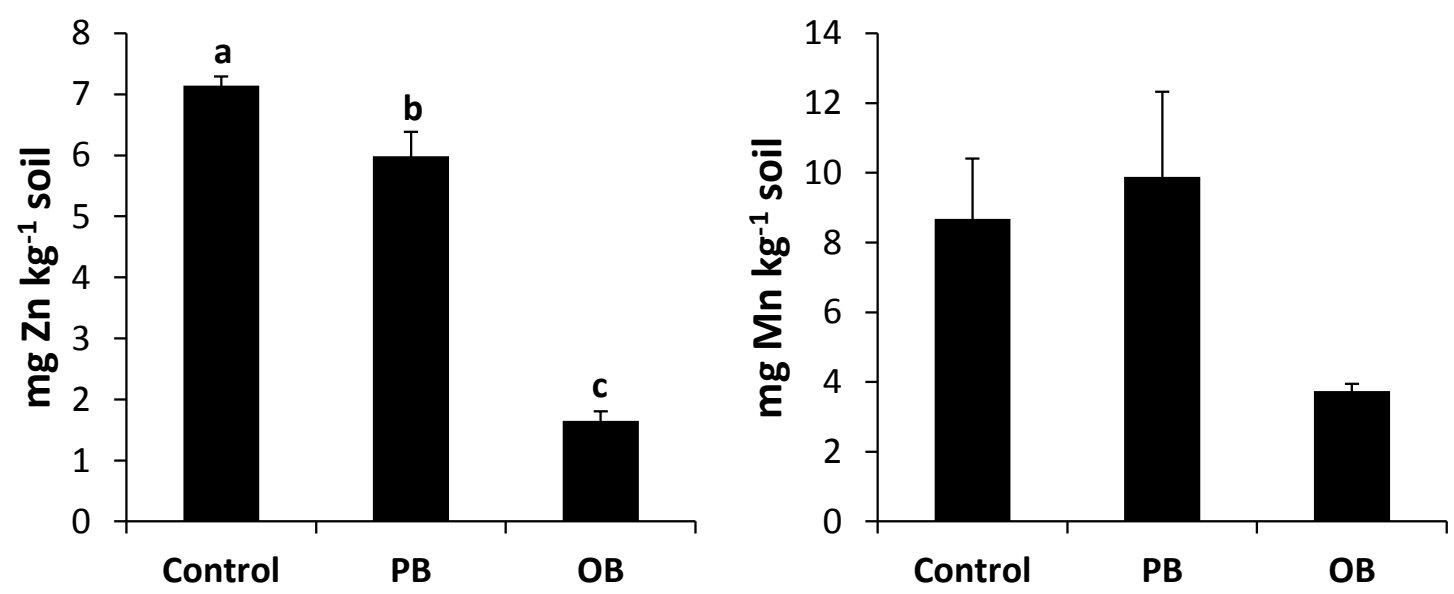

Fig. 5 Ammonium sulfate-extractable $\mathrm{Zn}$ and $\mathrm{Mn}$ in a mine soil with different biochar treatment (PB: pine woodchip biochar and OB: olive-tree pruning biochar). Mean $\pm \mathrm{SE}$ $(n=5)$. Different letters signify statistical differences between treatments at $\mathrm{p}<0.05$.
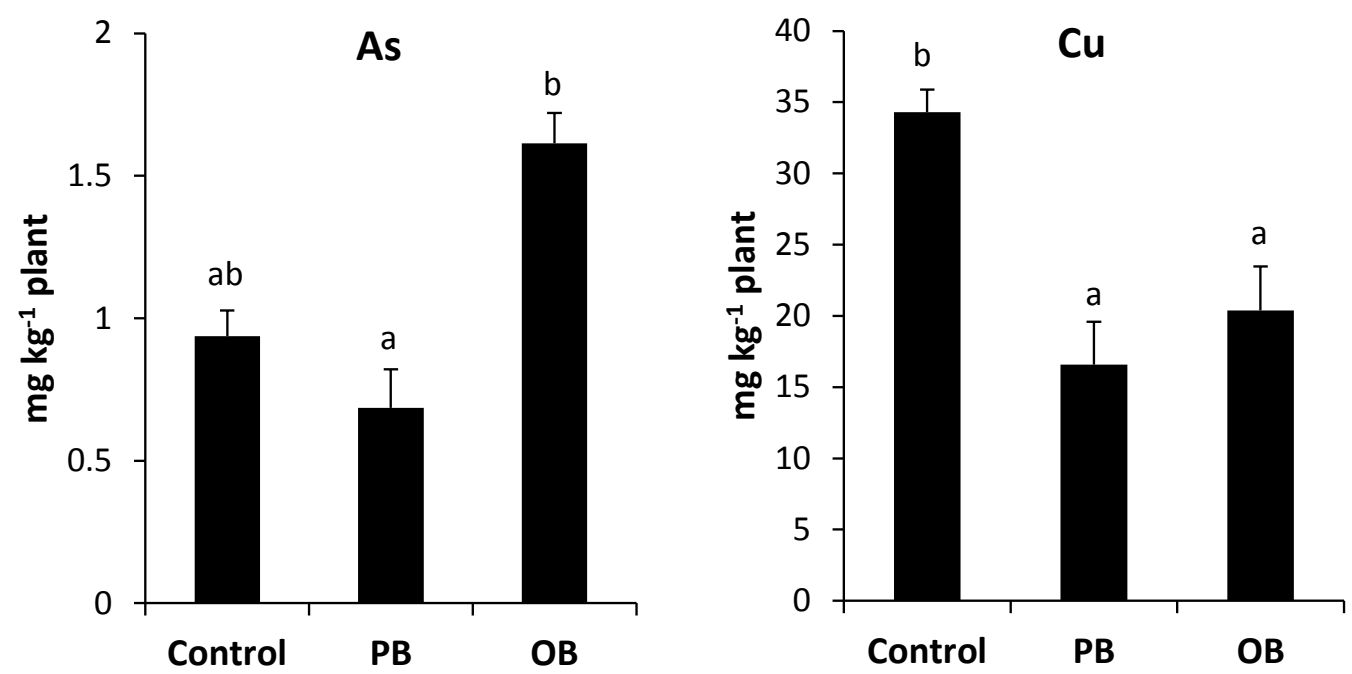

Fig. 6 Arsenic and copper concentration in shoots of maize plants growing on a mine soils with different biochar treatment (PB: pine woodchip biochar and OB: olive tree pruning biochar). Mean \pm SE $(n=4-5)$. Different letters mean statistical differences between groups at $\mathrm{p}<0.05$. 

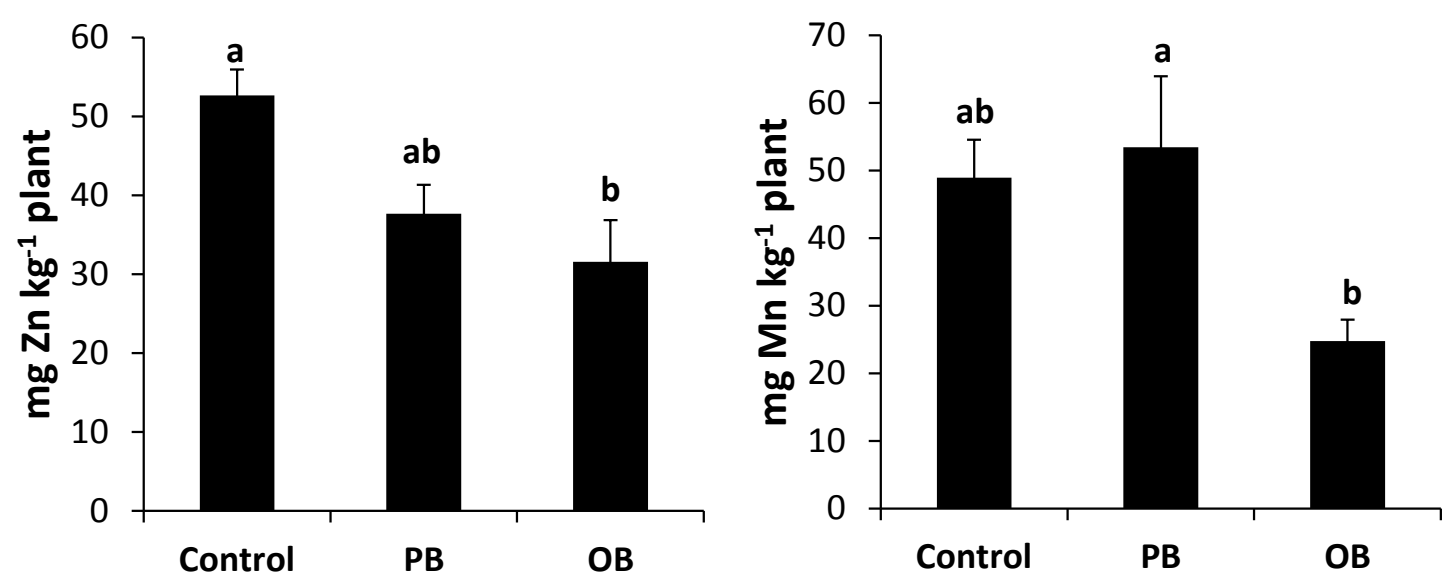

Fig. 7 Zinc and manganese concentration in shoots of maize plants growing on a mine soils with different biochar treatment (PB: pine woodchip biochar and OB: olive-tree pruning biochar). Mean \pm SE $(n=4-5)$. Different letters mean statistical differences between groups at $\mathrm{p}<0.05$.
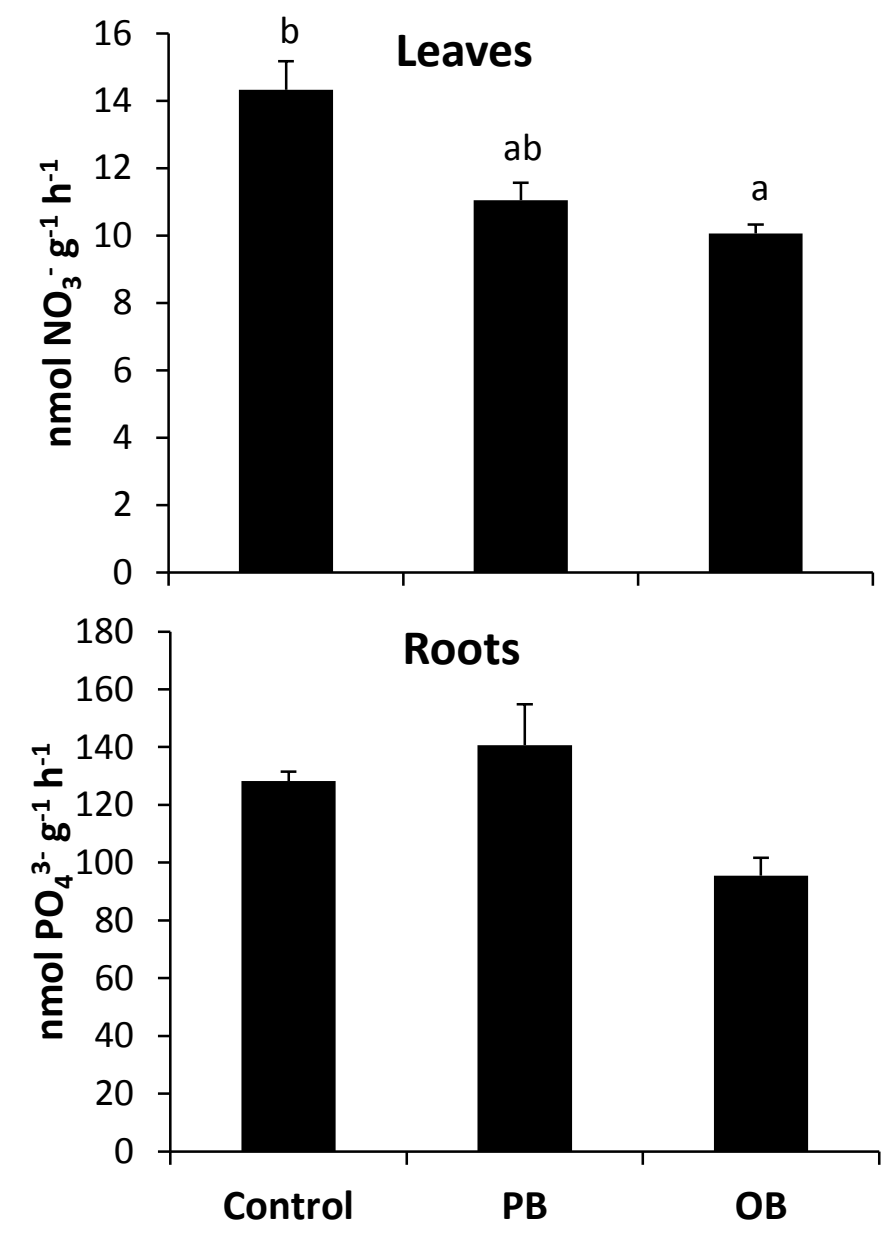

Fig. 8 Nitrate reductase activity in leaves and acid phosphatase activity in roots of maize growing on a mine soils with different biochar treatment (PB: pine woodchip biochar and OB: olive tree pruning biochar). Mean \pm SE $(n=3-5)$. Different letters signify statistical differences between groups at $\mathrm{p}<0.05$. 

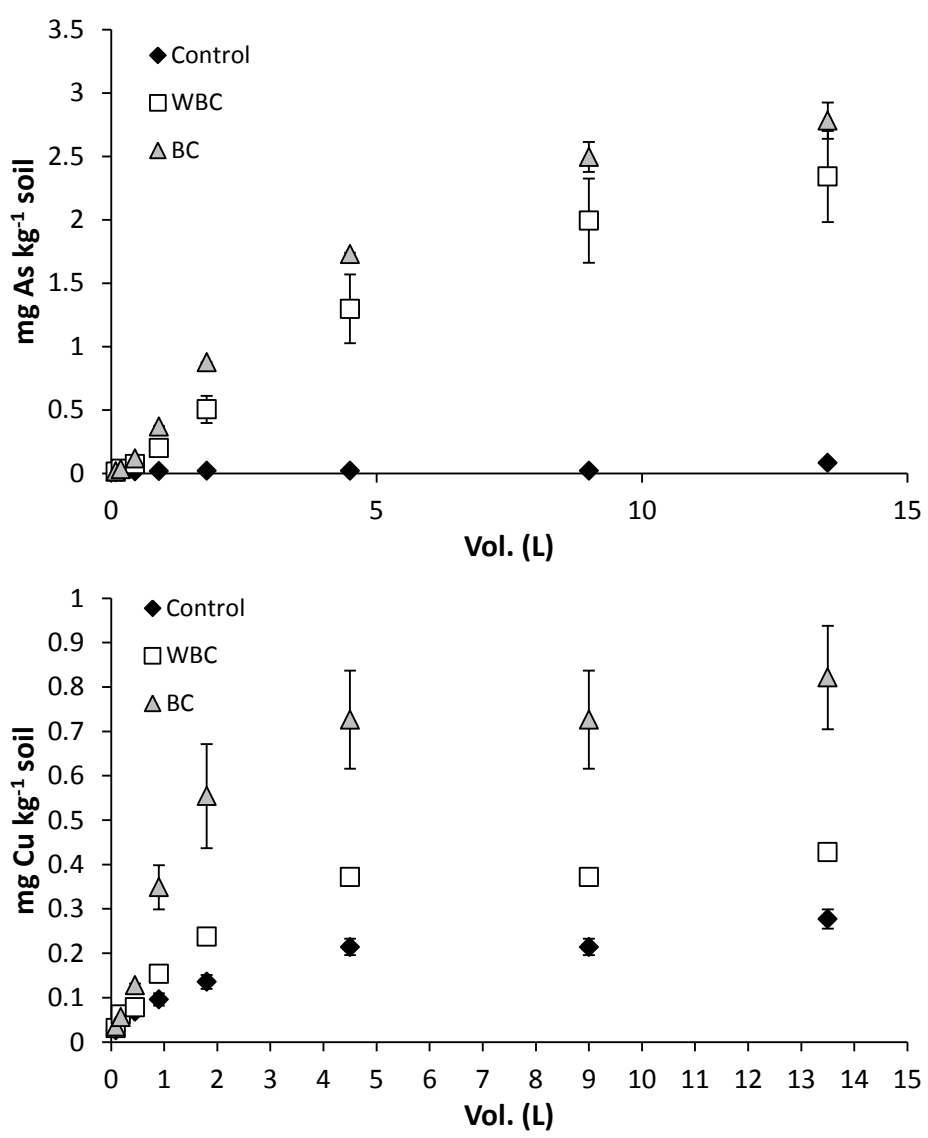

Fig. 9 Leaching of As (top) and $\mathrm{Cu}$ (bottom) in mg per kg of soil (on a dry weight basis) as evaluated by a leaching column experiment using washed (WBC) and unwashed (BC) olive tree pruning biochar over 14 days. Mean \pm SE $(n=2)$. 